\title{
Successful Treatment of Granuloma Faciale with Topical Tacrolimus: A Case Report and Immunohistochemical Study
}

\author{
Gen-ichi Tojo Taku Fujimura Yumi Kambayashi \\ Katsuko Kikuchi Setsuya Aiba
}

Department of Dermatology, Tohoku University Graduate School of Medicine, Sendai, Japan

\section{Key Words}

Granuloma faciale · Tacrolimus · Proinflammatory cytokine

\begin{abstract}
We report the case of a 55-year-old Japanese patient with granuloma faciale (GF) successfully treated with topical tacrolimus and describe the immunohistochemical study. Immunohistochemical staining revealed that the patient's granuloma contained $\mathrm{CD}^{+}, \mathrm{CD}^{+}$, $\mathrm{CD}^{+}, \mathrm{CD}^{+} 8^{+}$and $\mathrm{CD} 163^{+}$cells. Interestingly, these cells contained granulysin ${ }^{+} \mathrm{T}$ cells and lacked Foxp $3^{\text {hight }}$ regulatory T cells. In addition, the macrophages were mainly $\mathrm{CD} 163^{+}$, which suggested that the alternatively activated macrophage is one of the main components of GF. In summary, the present data shed light on the granuloma-composing cells and possible mechanisms in the treatment of GF with topical tacrolimus.
\end{abstract}

\section{Introduction}

Granuloma faciale (GF) is an uncommon disorder that mainly affects sun-exposed sites $[1,2]$. It is characterized by reddish-brown plaque, and the histopathology is diagnostic. Clinically, the differential diagnosis includes discoid lupus erythematosus, sarcoidosis and Jessner's lymphocytic infiltrate. The typical histopathological picture consists of a dense cellular infiltrate in the mid dermis with a grenz zone in the immediate subepidermis and with leukocytoclastic vasculitis $[1,2]$. It is reported that the granuloma-composing cells are mainly eosinophils, lymphocytes, neutrophils and histiocytes, but the profiles of these lymphocytes and histiocytes have not been reported in detail. In the present report, we investigated the immunohistochemical profiles of the granuloma-composing cells, not only focusing on the effector $\mathrm{T}$ cells but 
also on the immunosuppressive cells, such as regulatory T cells and skin-resident CD163+ macrophages.

\section{Case Report}

A 55-year-old Japanese man with a 2-year history of asymptomatic erythema on his nasal root visited our outpatient clinic. He had been treated with topical steroid and oral antihistamine for half a year without any improvement. On his initial visit, physical examination revealed dark, infiltrated erythema on his nasal root, $24 \times 14 \mathrm{~mm}$ in size (fig. 1a). A biopsy specimen revealed a prominent cellular infiltrate in the mid dermis with a grenz zone (fig. $2 \mathrm{a}$ ). The infiltrating cells were composed of eosinophils, lymphocytes, neutrophils and histiocytes. In the mid dermis, neutrophils were densely infiltrated around the vessels with deposition of fibrinoid (fig. 2b). The full blood count and biochemical profile were within normal ranges. From the above findings, we diagnosed GF. To further analyze the pathogenesis of GF, we performed immunohistochemical staining, which revealed that the granuloma-composing cells were $\mathrm{CD}^{+}, \mathrm{CD}^{+}$(fig. 2c) and CD8+ (fig. 2d) in the inflammatory areas. In addition, TIA1+ and granulysin ${ }^{+}$cells (fig. $2 \mathrm{f}$ ) were scattered in areas of vasculitis. Few Foxp $3^{\text {high }}{ }^{+}$cells were detected (fig. 2e). Macrophages were mainly CD163+ (fig. 2h), and CD68+ cells were scattered (fig. $2 \mathrm{~g}$ ). We treated the patient with topical $0.1 \%$ tacrolimus twice a day and the erythema diminished after 2 months (fig. 1b). One year after stopping tacrolimus, there was no sign of relapsing erythematous plaque.

\section{Discussion}

In this report, we describe a case of GF successfully treated with topical tacrolimus and the immunohistochemical study. Our present data shed light on the granulomacomposing cells and possible mechanisms in the treatment of GF with topical tacrolimus.

GF is a localized craniofacial leukocytoclastic vasculitis that presents as recurrent reddish-brown plaques on the forehead, cheek and ears [2]. It was reported that mononuclear and plasma cells are dominant at the inflammatory areas of GF. In the present case, indeed, almost no Foxp $3^{\text {hight }}$ regulatory $\mathrm{T}$ cells were detected, though numerous $\mathrm{CD}^{+} \mathrm{CD}^{+}$or $\mathrm{CD} 8+{ }^{+} \mathrm{T}$ cells were detected at granulomatous areas. Like psoriasis, the induced macrophages were mainly $\mathrm{CD} 163^{+}$macrophages, which were reported to produce proinflammatory cytokines such as IL-23 [3]. In addition, these infiltrating $\mathrm{CD}^{+}{ }^{+}$cells contained granulysin ${ }^{+}$cells, which were previously reported to contribute to severe cutaneous inflammatory disorders, such as toxic epidermal necrolysis [4]. In summary, one possible pathogenesis of GF might be associated with these proinflammatory circumstances.

Though previous reports suggested possible therapies for GF, such as intralesional corticosteroids, dapsone, cryosurgery, surgical excision and pulse dye laser [5-8], based on the above findings, we selected topical administration of $0.1 \%$ tacrolimus ointment. Topical tacrolimus has recently been shown to be an effective treatment for GF $[9,10]$. Tacrolimus contains an immunosuppressive agent that inhibits $\mathrm{T}$ cell proliferation and production of several proinflammatory cytokines, such as IL-2, IL-4, IL-5, IFN- $\gamma$ and TNF- $\alpha$ [11]. Interestingly, a previous report also suggested that topical administration of tacrolimus ointment increased the number of IL-10 producing cells and enhanced the production of TGF- $\beta$ [11]. Regarding GF, Gauger et al. [12] previously reported that increased levels of IL-5 in the lesional skin might contribute to the 
pathogenesis of GF. In our present case, indeed, the eruption diminished after 2 months of topical administration of $0.1 \%$ tacrolimus. In summary, topical administration of tacrolimus might suppress the proinflammatory cytokines and induce immunosuppressive cells in GF.

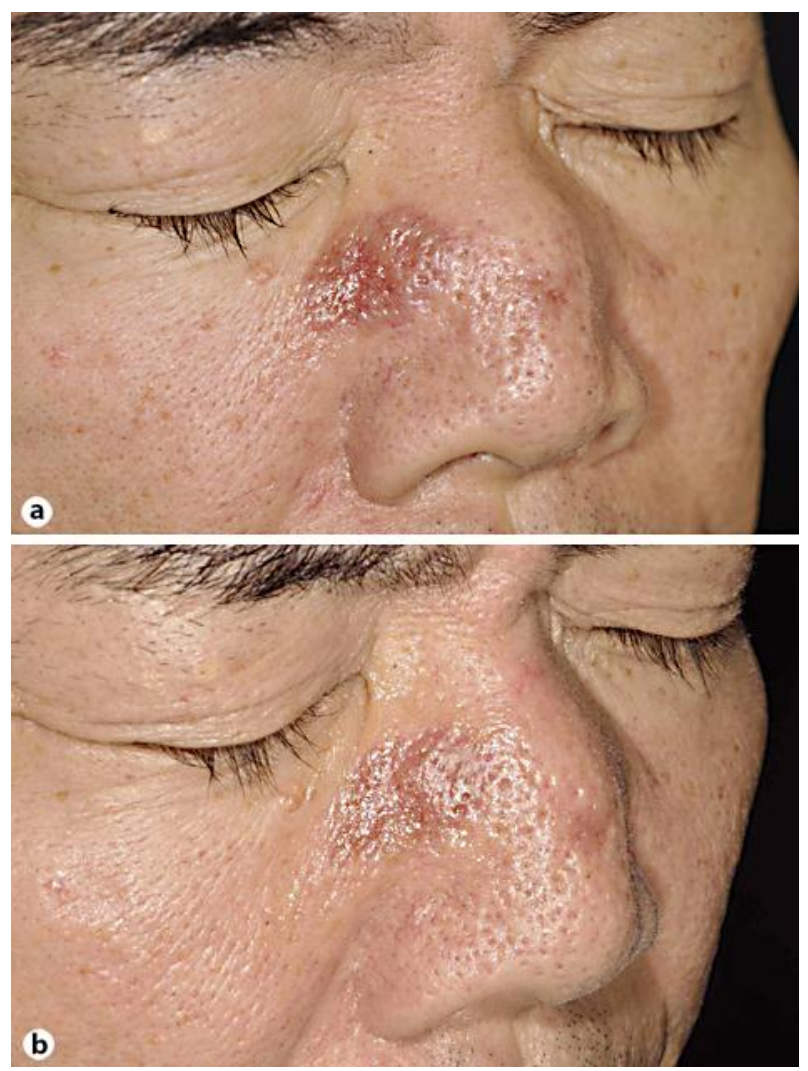

Fig. 1. Dark, infiltrated erythema on the nasal root, $24 \times 14 \mathrm{~mm}$ in size, before (a) and after (b) the administration of topical tacrolimus. 

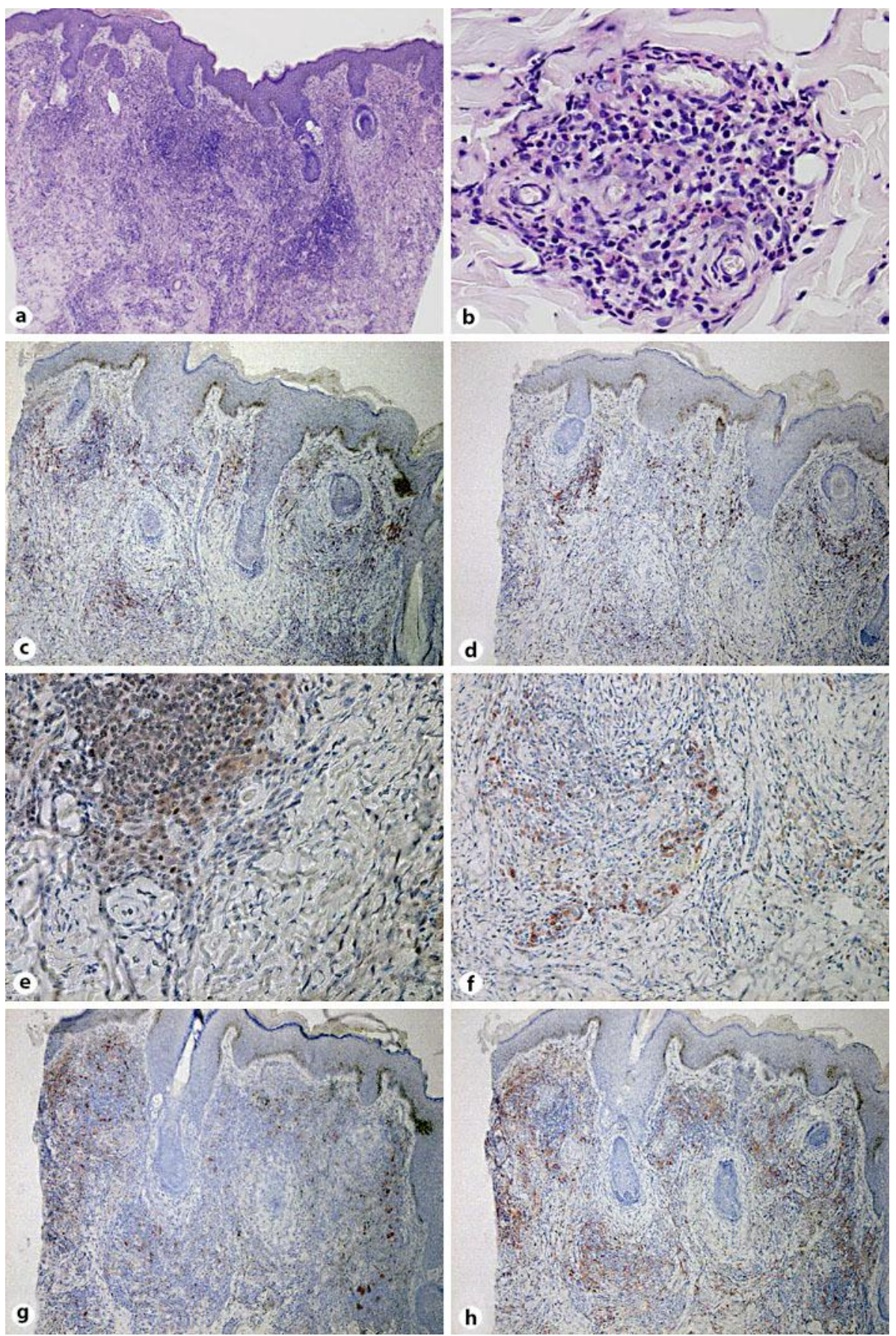

Fig. 2. Prominent cellular infiltrate in the mid dermis with a grenz zone (a). Neutrophils were densely infiltrated around the vessels with deposition of fibrinoid (b). H\&E staining, original magnification $\times 50(a), \times 400($ b). Paraffin-embedded tissue samples from the patient were stained as follows: the sections were developed with new fuchsin for CD4 (c), CD8 (d), Foxp3 (e), granulysin (f), CD68 (h), and CD163 (g). Original magnification $\times 100(\mathbf{c}, \mathbf{d}, \mathbf{g}, \mathbf{h}), \times 200(\mathbf{f}), \times 400(\mathbf{e})$. 


\section{References}

1 Ortonne N, Wechsler J, Bagot M, Grosshans E, Cribier B: Granuloma faciale: a clinicopathologic study of 66 patients. J Am Acad Dermatol 2005;53:1002-1009.

2 Crowson AN, Mihm MC, Magro CM: Cutaneous vasculitis: a review. J Cutan Pathol 2003;30:161-173.

-3 Fuentes-Duculan J, Suárez-Fariñas M, Zaba LC, Nograles KE, Pierson KC, Mitsui H, Pensabene CA, Kzhyshkowska J, Krueger JG, Lowes MA: A subpopulation of CD163-positive macrophages is classically activated in psoriasis. J Invest Dermatol 2010;130:2412-2422.

4 Schlapbach C, Zawodniak A, Irla N, Adam J, Hunger RE, Yerly D, Pichler WJ, Yawalkar N: NKp46+ cells express granulysin in multiple cutaneous adverse drug reactions. Allergy 2011;66:1469-1476.

5 De D, Kanwar AJ, Radotra BD, Gupta S: Extrafacial granuloma faciale: report of a case. J Eur Acad Dermatol Venereol 2007;21:1284-1286.

-6 Requena C, Castejón P, Sanmartín O, Botella-Estrada R, Nagore E, Serra-Guillén C, Sorní G, Guillén C: Rhinophyma-like granuloma faciale. J Eur Acad Dermatol Venereol 2006;20:881-882.

7 Panagiotopoulos A, Anyfantakis V, Rallis E, Chasapi V, Stavropoulos P, Boubouka C, Katsambas A: Assessment of the efficacy of cryosurgery in the treatment of granuloma faciale. Br J Dermatol 2006;154:357-360.

8 Hruza GJ, Ammirati CT: Granuloma faciale treated with 595-nm pulsed dye laser. Dermatol Surg 2011;37:1060-1061.

-9 Patterson C, Coutts I: Granuloma faciale successfully treated with topical tacrolimus. Australas J Dermatol 2009;50:217-219.

10 Cecchi R, Pavesi M, Bartoli L, Brunetti L: Topical tacrolimus in the treatment of granuloma faciale. Int J Dermatol 2010;49:1463-1465.

11 Caproni M, Torchia D, Antiga E, Volpi W, del Bianco E, Fabbri P: The effects of tacrolimus ointment on regulatory T lymphocytes in atopic dermatitis. J Clin Immunol 2006;26:370-375.

12 Gauger A, Ronet C, Schnopp C, Abeck D, Hein R, Köhn FM, Ring J, Ollert M, Mempel M: High local interleukin 5 production in granuloma faciale (eosinophilicum): role of clonally expanded skin-specific CD4+ cells. Br J Dermatol 2005;153:454-457. 